\title{
Workplace Spirituality- A New Paradigm in Management
}

\author{
Anshul Anil Kumar Gupta*
}

\section{Abstract}

Workplace spirituality has been researched for a decade and while there have been papers studying the same, it is still not adequately applied in real-time in the workplace. This is due to the major constraint of lack of systems approach to the entire gamut of the input, throughput and output of the workplace spirituality systems and processes. There is also a lot of confusion surrounding the definition and the meaning of the concept of workplace spirituality. This paper attempts to fill this gap in research by putting together the various dimensions of workplace spirituality. It addresses the various implications for organizations and relates it to motives beyond the bottom line for managers and organizations at large. This paper is concluded with a model which may be empirically tested in further studies. The major contribution of this paper is in the form of compiling all major research studies in the form of an empirically testable model.

Keywords: Workplace, Spirituality, Management, New paradigm.

\section{Introduction}

A "burgeoning new field of spirituality in the organizations has emerged" and "Workplace spirituality" is a common term used to refer to this field (Benefiel, 2003). Workplace spirituality, as a field

* Institute of Management, Christ University, Bangalore, India; anshul.gupta@res.christuniversity.in 
of inquiry is new, but important. Researchers have noted the newness of this field by indicating that it is emerging. It has been termed a 'new paradigm' in the organizational sciences (Jurkiewicz \& Giacalone, 2004). It has also been termed "new" (Duchon D, 2005) and "Young" (Sheep, 2006). However, although relatively new it has been described as a "movement" (Gotsis, 2008).

"Spirituality at work", "Spirituality in work", "Workplace Spirituality", "Spirituality in the workplace" are some of the terms used by various authors to title their work in relation with spirituality, work and workplace between 1970-2008 as stated in the bibliometric analysis on workplace spirituality presented at IIM Bangalore (Narendran \& Gourlay, 2015).

In modern times there has been an uptake in the study of spirituality at work due to various reasons of increased attrition, absenteeism, decreased engagement and declining productivity of employees and more so because of ethical failures of reputed organizations such as, Enron, Arthur, Anderson, WorldCom, Satyam Computers and the like have shaken the faith of the business world (Gupta, Kumar, \& Singh, 2014). This has created the need for a fresh approach to managing the human resource in organizations. (Neck, 2002)

\section{Defining Spirituality at work}

Mathew (1994) said that "spirituality at work begins with acknowledging that people have both an inner and an outer life and that the nourishment of the inner life can lead to a more meaningful and productive outer life."

M. Kinjerski \& Skrypnek (2004) defined spirituality at work as "a distinct state that is characterized by physical, affective, cognitive, interpersonal, spiritual and mystical dimensions. Most individuals describe the experience as including any one or more of the following:

- a physical sensation characterized by a positive state of arousal or energy

- positive effects characterized by a profound feeling of wellbeing and joy 
- cognitive features involving a sense of being authentic

- an awareness of alignment between one's values and beliefs and one's work

- the belief that one is engaged in meaningful work that has a higher purpose

- an interpersonal dimension characterized by a sense of connection to others and common purpose

- a spiritual presence characterized by a sense of connection to something larger than the self, such as higher power, the universe, nature or humanity; and

- a mystical dimension characterized by a sense of perfection, transcendence, living in the moment and experiences that were awe-inspiring, mysterious or sacred.

Workplace spirituality has been defined at two levels - individual spirituality and organizational spirituality. Individual spirituality is the acknowledgement that employees have an inner life that needs to be nourished. It further acknowledges that employees seek the larger mission of their lives through work and therefore, engaging the soul of employees is the highest form of employee engagement (Ashmos \& Duchon, 2009; Mitoff, 1999). On the other hand, organizational spirituality refers to a "corporate soul" and is indicative of the work environment provided by the employer to the employees. It refers to both the top line - the purpose of the existence of the organization and the bottom line - profitability. Workplace spirituality is said to be an interactive outcome of individual and organizational spirituality (Kolodinsky et al., 2008). By measuring workplace spirituality, it is possible to develop a person-organization fit approach to the entire gamut of HR processes (Manish Singhal, 2014).

\section{Dimensions of Workplace Spirituality}

Meaningful work implies that the work should be such that employees see meaning in their lives through work; That ignites their spirit and engages their soul. A thorough understanding of the work, its requirements and the personality/background of the incumbent is vital to establish this dimension (John Milliman, 
2003). Interconnectedness means the employees need to experience a feeling of belongingness and attachment to the place of work. They need to be told that they "belong" to the place of work and they can be as at ease with themselves at work as they are in their personal lives. They should be made comfortable sharing their emotions at work (Ashmos \& Duchon, 2000). Compassion in organizational culture manifests when treating employees with utmost care is the foremost motive of the management, even higher in value than making profits (Petchsawanga \& Duchon, 2009). The existence of a fulfilling inner life means a more satisfied and fulfilling outer life. Workplace spirituality is acknowledging the existence of inner life in organizations (Petchsawanga \& Duchon, 2009) and Alignment with Organizational values is about aligning your goals with the organizational goals and leading a fulfilling life through work. (Mitroff, 1999)

\section{Positive implications for the organization}

As the employee works holistically and there is alignment in the individual and the organizational goals, the culture established is of collaboration rather than competition, a perfect recipe for increased job performance and resultant profitability is at place (Neck, 2002). When employees do not experience stress and tension at the workplace, they feel happy and fulfilled in their place of work; they experience less stress and a consequent decline in stressrelated bodily ailments. Employees would want to work despite slight discomfort when their work is a source of healing for their souls and they can rest assured that there will be no further injury to their body and mind at work (Marques, Dhiman, \& King, 2007). The employees that feel a purpose in life through work and feel treated with respect and care will find no reason to not to go beyond the call of their duty to attain organizational goals and meet their performance parameters. They will not find reasons to cover their failure but reasons to make them convert failures to success (Pawar, 2009). Research studies have (John Milliman, 2003; Rego et al., 2008; Fry, 2003; Pawar, 2009) concluded that a sense of community could have a positive impact on the affective and normative commitment levels of employees. It can also help achieve alignment withorganizational values and a sense of purpose at work, which relates positively to the levels of 
organizational commitment experienced by the employees. Meaningful work, Sense of community and Organizational values have a positive correlation with workplace spirituality (Gupta, Kumar, \& Singh, 2014). Intrinsic work satisfaction increases with increased workplace spirituality. Milliman (2003) states that with an increase in workplace spirituality extrinsic job satisfaction and reward satisfaction also increases (Kolodinsky, Giacalone, \& Jurkiewicz, 2008).

\section{Advantages beyond the bottom line}

The above dimensions of workplace spirituality and their implications on the various organizational behaviour subsets result in organizations turning into learning organizations (Porth, Macall, \& Bausch, 2006), further leading the spirituality applied at work into a competitive advantage for the organization. The implementation of spirituality at work not only enhances the chances of achievement of business objectives but allows human beings to flourish within organizations. Luthans, Luthans, \& Luthans (2004) have stated "With the rising recognition of human resources as a competitive advantage in today's global economy, human capital and, more recently, social capital isbeing touted in both theory, research, and practice. To date, however, positive psychological capital has been virtually ignored by both business academics and practitioners. "Who I am" is every bit as important as "what I know" and "who I know." By eschewing a preoccupation with personal shortcomings and dysfunctions and focusing instead on personal strengths and good qualities, today's leaders and their associates can develop confidence, hope, optimism, and resilience, thereby improving both individual and organizational performance."

The answer to "who am I" is the recognition that the employees have an inner life that needs nourishment (Petchsawanga \& Duchon, 2009). This recognition and nourishment of inner life of the organization, by employing a person-organization fit approach, is the new way of managing human resource "Workplace Spirituality" (Singhal, 2014). 


\section{The integrated model}

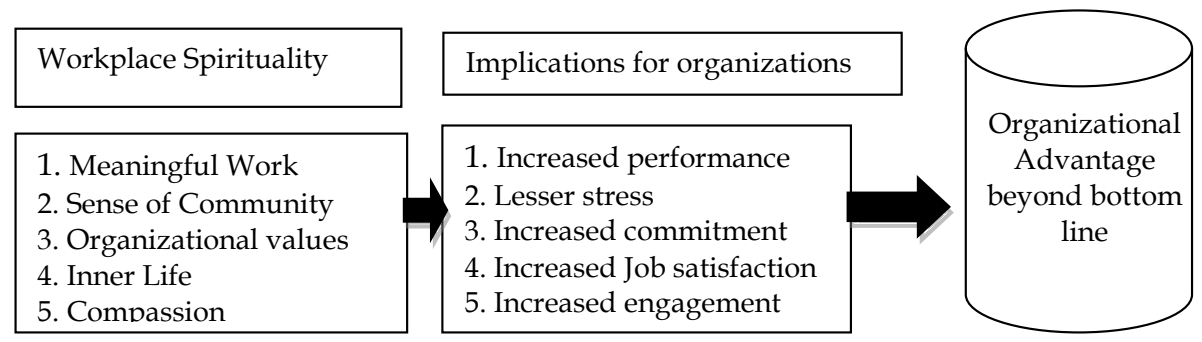

\section{Contribution and Limitation}

This paper contributes in the form of addressing the major concern of scattered data on workplace spirituality research and brings the concept expressed by various authors onto a singular unified platform. Until now the research conducted in this field has been fragmented (Tischler, 1999). Secondly, this paper provides the perspective of a learning organization and explores a sustained competitive advantage for the organization, which is the need of today's competitive world.

\section{Future Research}

Future research should examine the various models implementing workplace spirituality so that organizations have a structure in place for implementing the paradigm. It is also essential that there is more industry-specific empirical research in the Indian context so that the construct of workplace spirituality is acclimatized and thus becomes implementable. Future research must also provide a word of caution in implementing workplace spirituality due to the lack of research on the practical limitations of the same (Polley, Vora, \& Subbanarasimha, 2005).

\section{Implications for practice}

The paper suggests that by implementing the dimensions of workplace spirituality the organization's human resource benefits in a holistic manner and critical organizational behaviour concepts are implemented as precursors to workplace spirituality (Pawar, 2009). This paper aligns the concept of workplace spirituality, not only to organizational profitability but also to the collective 
knowledge base of the organization, which is a prerequisite for success in the knowledge economy.

\section{Conclusion}

In conclusion, this paper brings the fresh perspective to the emerging field of research in management-“Workplace spirituality". The implications of the research give further direction towards generating more empirical evidence with regard to managing spirituality at work. The scope of future research could extend to empirically weighing the pros and cons of this fresh paradigm in order to enable the industry to take decisions on whether to imbibe spiritual values at work and to also limit the usage of the same.

\section{References}

Ashmos, D. P., \& Duchon, D. (2000). Spirituality at work: A conceptualization and measure. Journal of management inquiry, 9(2), 134-145.

Duchon, D., \& Plowman, D. A. (2005). Nurturing the spirit at work: Impact on work unit performance. The leadership quarterly, 16(5), 807833.

Fry, L. W. (2003). Toward a theory of spiritual leadership. The leadership quarterly, 14(6), 693-727.

Gotsis, G., \& Kortezi, Z. (2008). Philosophical foundations of workplace spirituality: A critical approach. Journal of business ethics, 78(4), 575600.

Gupta, M., Kumar, V., \& Singh, M. (2014). Creating satisfied employees through workplace spirituality: A study of the private insurance sector in Punjab (India). Journal of business ethics, 122(1), 79-88.

Jurkiewicz, C. L., \& Giacalone, R. A. (2004). A values framework for measuring the impact of workplace spirituality on organizational performance. Journal of business ethics, 49(2), 129-142.

Kinjerski, V., \& Skrypnek, B. J. (2008). Four Paths to Spirit at Work: Journeys of Personal Meaning, Fulfillment, Well- Being, and Transcendence through Work. The Career Development Quarterly, 56(4), 319-329.

Kolodinsky, R. W., Giacalone, R. A., \& Jurkiewicz, C. L. (2008). Workplace values and outcomes: Exploring personal, organizational, and interactive workplace spirituality. Journal of business ethics, 81(2), 465480 . 
Krishnakumar, S., \& Neck, C. P. (2002). The "what", "why" and "how" of spirituality in the workplace. Journal of managerial psychology, 17(3), 153164.

Luthans, F., Luthans, K. W., \& Luthans, B. C. (2004). Positive psychological capital: Beyond human and social capital. Business Horizons, 47(1), 45-50.

Marques, J. (2010). Spirituality, meaning, interbeing, leadership, and empathy: SMILE. Interbeing, 4(2), 7.

Marques, J., Dhiman, D. S., \& King, D. R. (2007). Spirituality in the workplace. USA: Personhood press.

Mathew, A. (2016). Career Expectations and Organizational Commitment of Millennials in Indian IT Industry-An SHRM Perspective. The International Journal of Business $\mathcal{E}$ Management, 4(1), 213.

Milliman, J., Czaplewski, A. J., \& Ferguson, J. (2003). Workplace spirituality and employee work attitudes: An exploratory empirical assessment. Journal of organizational change management, 16(4), 426-447.

Milliman, J., Ferguson, J., Trickett, D., \& Condemi, B. (1999). Spirit and community at Southwest Airlines: An investigation of a spiritual valuesbased model. Journal of organizational change management, 12(3), 221-233.

Mitroff, I. I., \& Denton, E. A. (1999). A study of spirituality in the workplace. MIT Sloan Management Review, 40(4), 83.

Narendran, S., \& Gourlay, S. (2016). Workplace spirituality: a bibliometric analysis.

Pawar, B. S. (2009). Some of the recent organizationalbehavior concepts as precursors to workplace spirituality. Journal of business ethics, 88(2), 245261.

Petchsawang, P., \& Duchon, D. (2009). Measuring workplace spirituality in an Asian context. Human resource development international, 12(4), 459-468.

Polley, D., Vora, J., \& SubbaNarasimha, P. N. (2005). Paying the devil his due: Limits and liabilities of workplace spirituality. International journal of organizational analysis, 13(1), 50-62.

Porth, S. J., McCall, J., \& Bausch, T. A. (1999). Spiritual themes of the "learning organization". Journal of Organizational Change Management, 12(3), 211-220.

Rego, A., \& Pina e Cunha, M. (2008). Workplace spirituality and organizational commitment: an empirical study. Journal of organizational change management, 21(1), 53-75.

Tischler, L. (1999). The growing interest in spirituality in business: A longterm socio-economic explanation. Journal of Organizational Change Management, 12(4), 273-280.

Vallabh, P., \& Singhal, M. (2014). Workplace spirituality facilitation: A person-organization fit approach. Journal of human values, 20(2), 193-207. 